
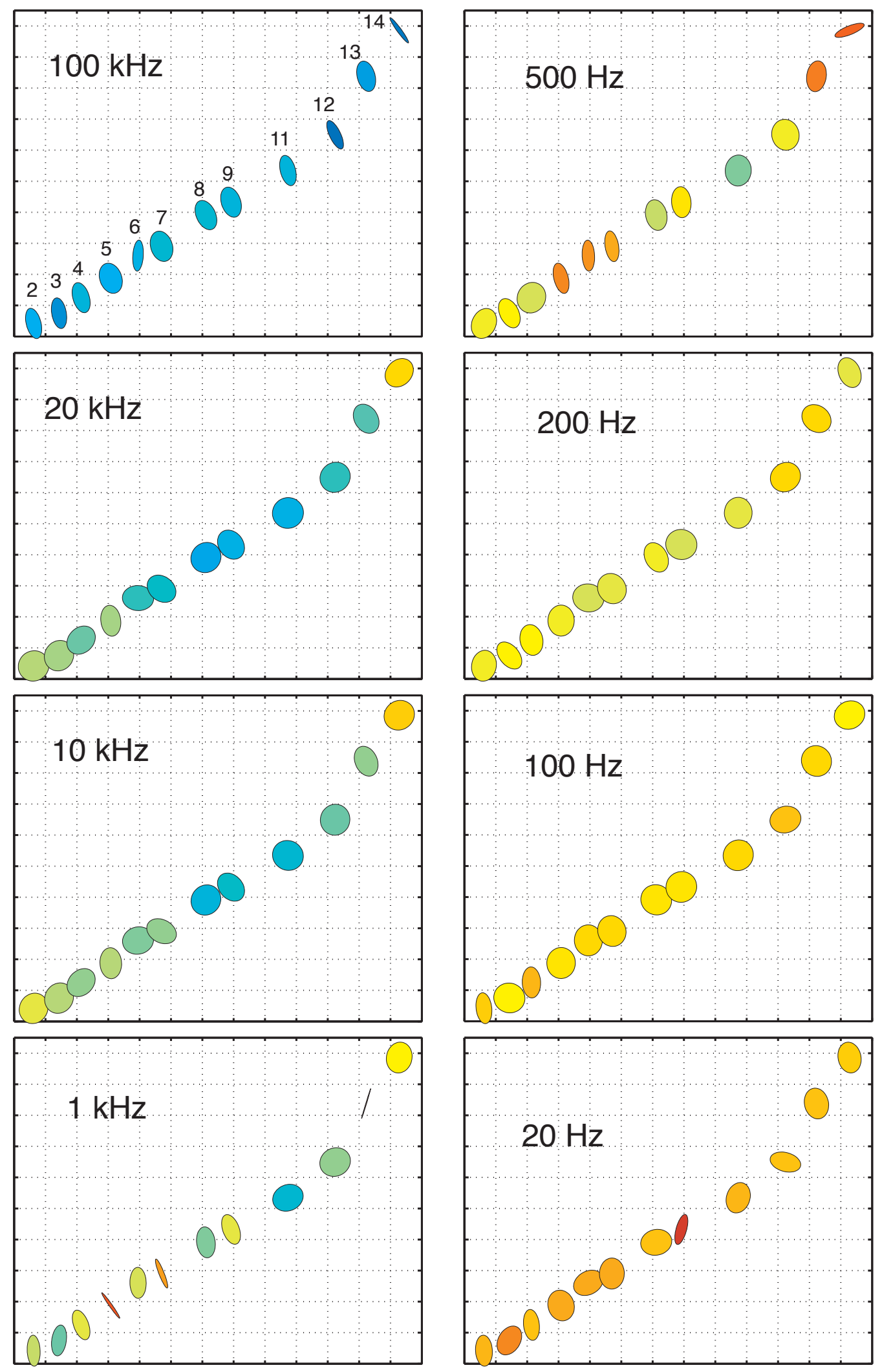

$\frac{02200400}{m}$

Figure DR1a

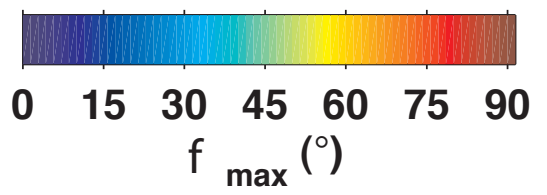



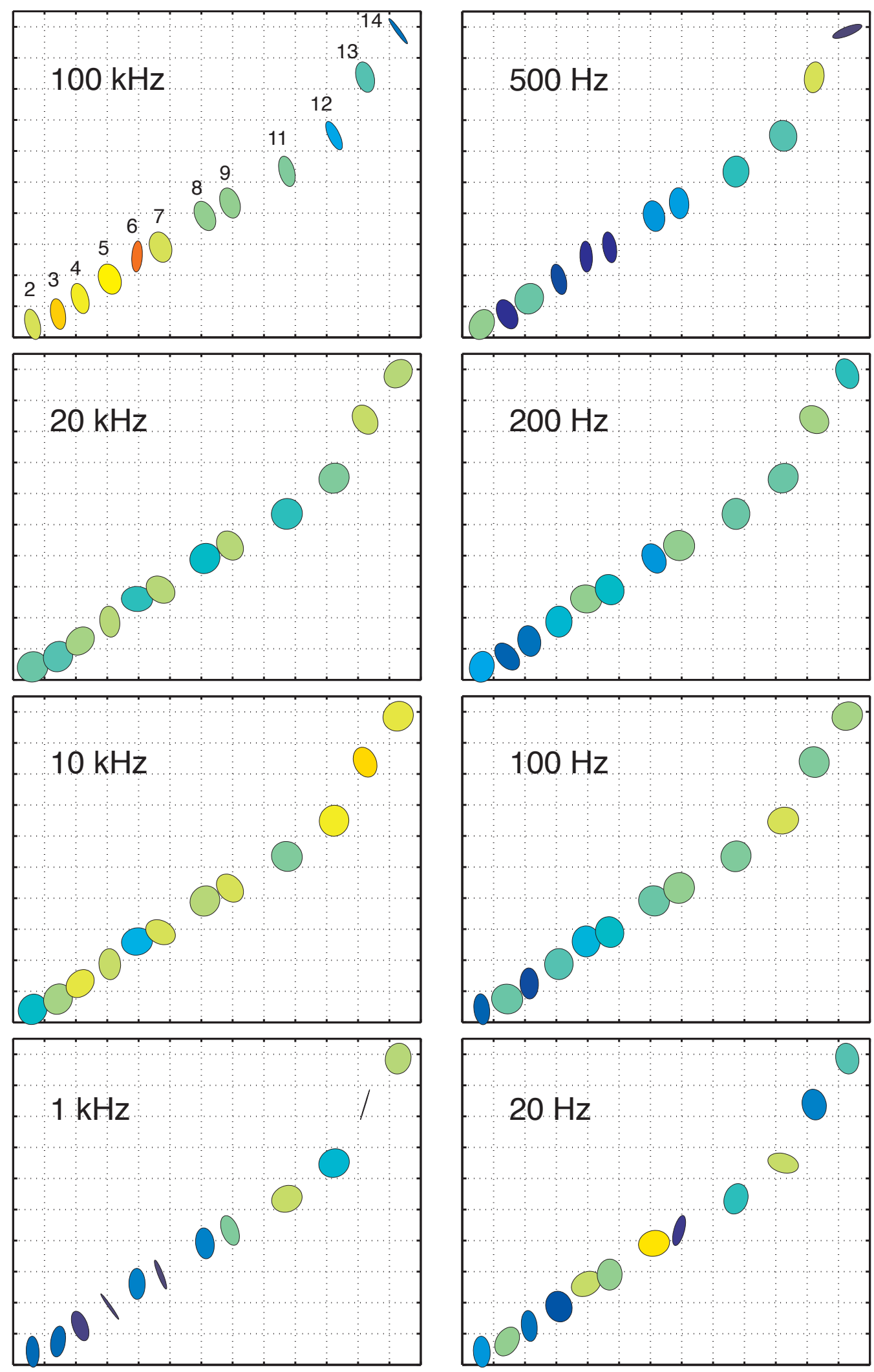

$\frac{0200400}{m}$

Figure DR1b

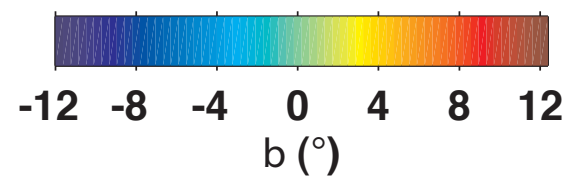




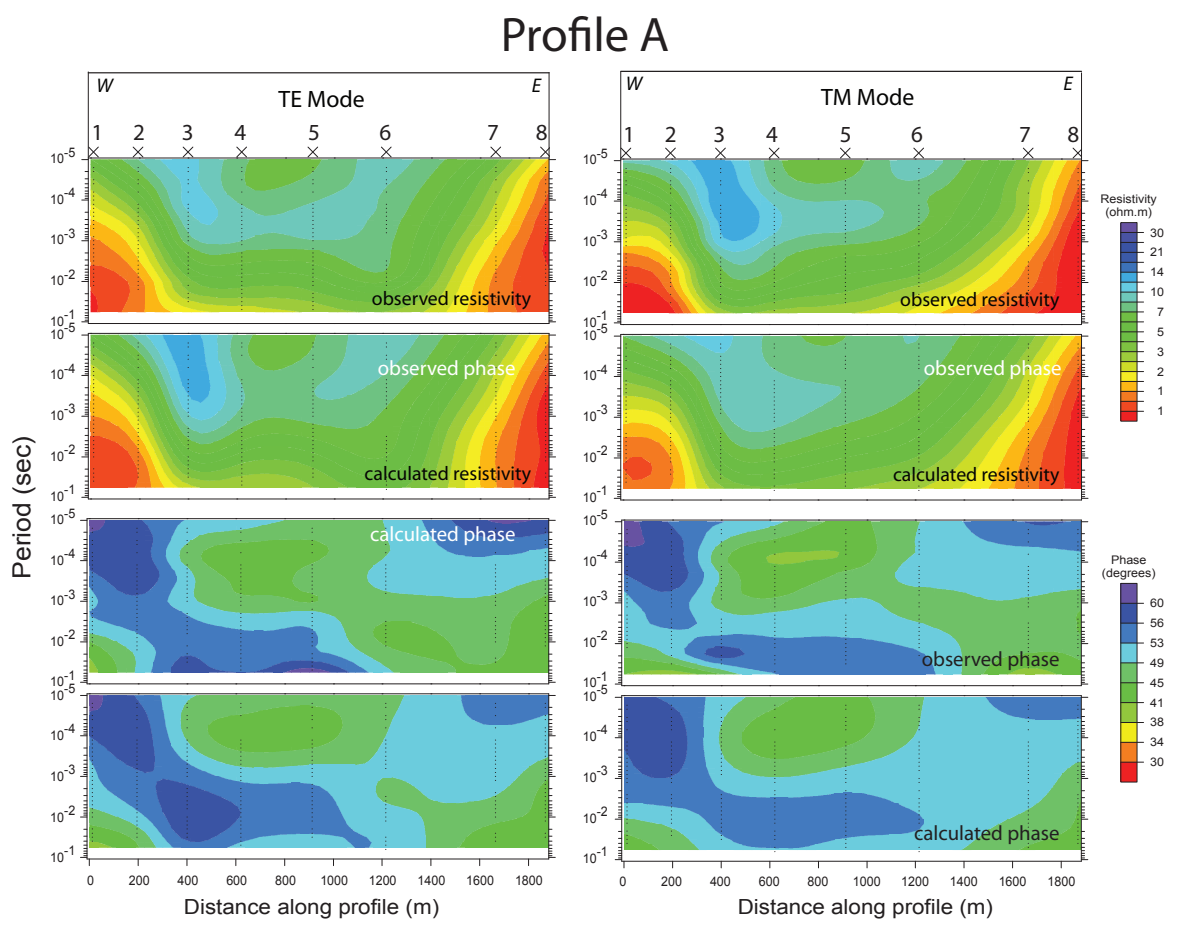

(a)

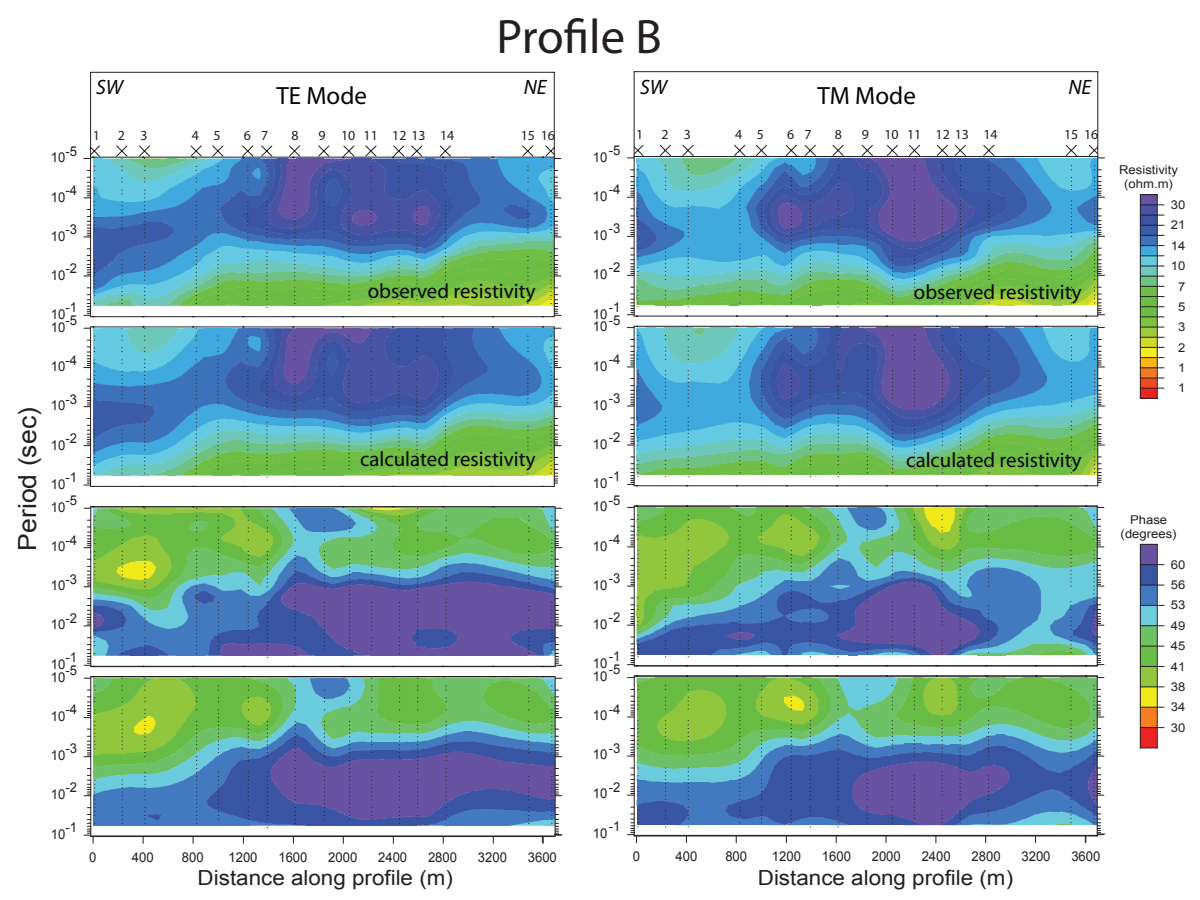

Figure DR2

(b) 


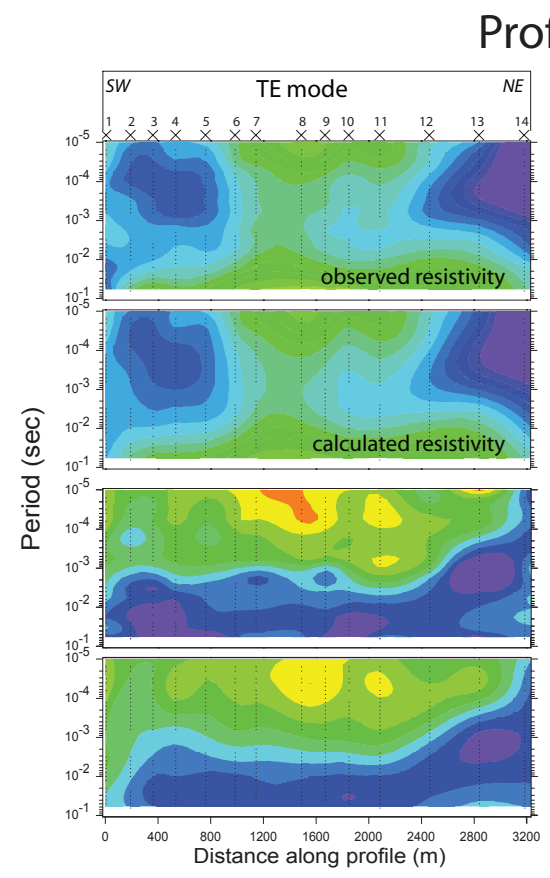

\section{file C}
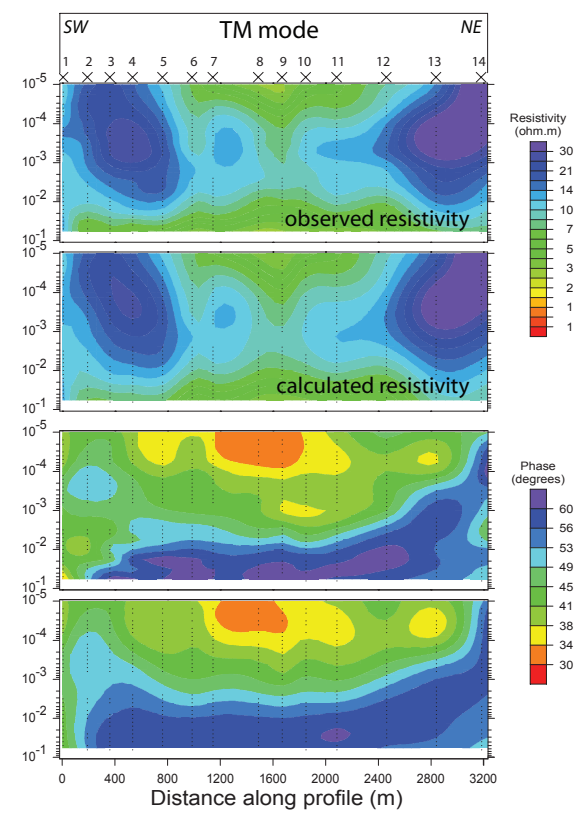

(c)

Figure DR2, cont. 

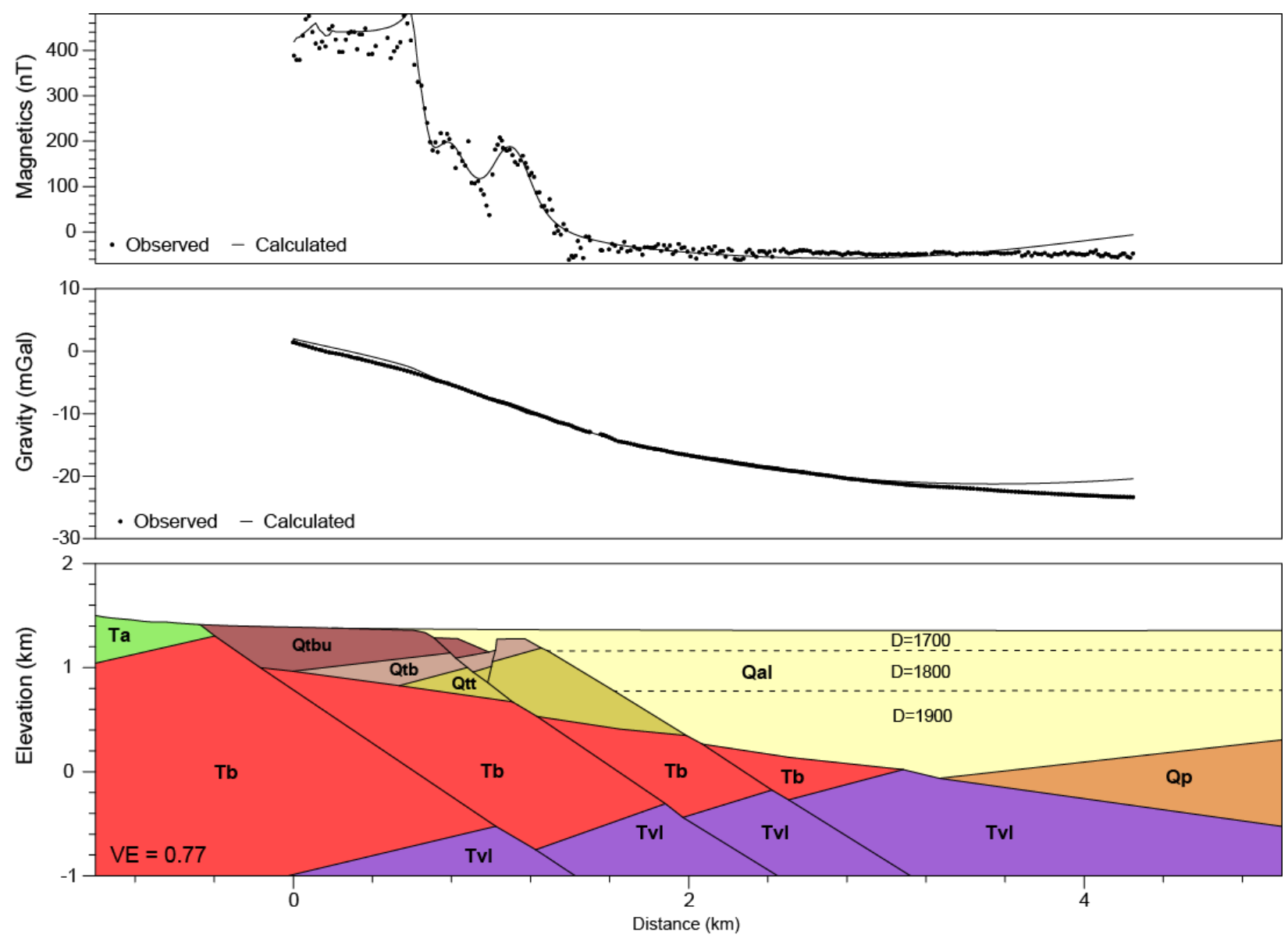

Figure DR3.

Table DR1.

\begin{tabular}{|l|l|c|c|c|c|c|}
\hline Unit & Description & $\begin{array}{c}\text { Density } \\
\left(\mathbf{g} / \mathbf{c m}^{\mathbf{3}} \mathbf{)}\right.\end{array}$ & $\begin{array}{c}\text { Susceptibility } \\
\mathbf{( S I )}\end{array}$ & $\begin{array}{c}\text { Magnetization } \\
\mathbf{( A / m )}\end{array}$ & $\begin{array}{c}\text { Magnetic } \\
\text { inclination }\end{array}$ & $\begin{array}{c}\text { Magnetic } \\
\text { declination }\end{array}$ \\
\hline Qal & $\begin{array}{l}\text { Quaternary } \\
\text { alluvium }\end{array}$ & $1.7-1.9$ & 0.001 & 0.004 & 65 & 0 \\
\hline Qaf1 & $\begin{array}{l}\text { Likely alluvial } \\
\text { fan deposits }\end{array}$ & 2.10 & 0.02 & 0.5 & 65 & 0 \\
\hline Qaf2 & $\begin{array}{l}\text { Likely alluvial } \\
\text { fan deposits }\end{array}$ & 2.10 & 0.01 & 0.5 & 65 & 0 \\
\hline Qaf3 & $\begin{array}{l}\text { Likely alluvial } \\
\text { fan deposits }\end{array}$ & 2.00 & 0.01 & 0.2 & 65 & 0 \\
\hline Qp & $\begin{array}{l}\text { Pleistocene } \\
\text { alluvium }\end{array}$ & 2.10 & 0.005 & 0.2 & 65 & 0 \\
\hline Ta & $\begin{array}{l}\text { Oligocene } \\
\text { andesites }\end{array}$ & Not included in model & & & 0 \\
\hline $\mathrm{Tb}$ & $\begin{array}{l}\text { Oligocene } \\
\text { basalts }\end{array}$ & 2.65 & 0.025 & 2 & 65 & 0 \\
\hline $\mathrm{Tvl}$ & $\begin{array}{l}\text { Older Tertiary } \\
\text { volcanic rocks }\end{array}$ & 2.67 & 0.03 & 0.5 & & 0 \\
\hline
\end{tabular}




\section{Figure captions}

Figure DR1. Phase tensor diagrams (Caldwell et al., 2004) for select AMT stations (numbered in the top left panel) along Profile $\mathrm{C}$ at eight frequencies colored by (a) azimuth of the major axis, $f_{\max }$, and (b) the skew angle, $b$. The azimuth of the major axis of the ellipse, $f_{\max }$, gives an indication, with a 90 degree ambiguity, of the geo-electric strike angle. For 2D structure, the direction of the phase tensor major axis is constant laterally and across a range of frequencies. The skew angle, $b$, is an indicator of 3D structure, where a high ( $>4$ degrees) skew angle indicates a 3D conductivity structure. The combination of a constant phase tensor major axis orientation and a low skew angle are indications of 2D structure. Note, the data at mid-band frequencies $(500-2000 \mathrm{~Hz})$ are particularly noisy as compared to data in higher or lower frequency bands, and the variations in $\mathrm{f}_{\max }$ and $\mathrm{b}$ in this mid-band are likely due to noise. The same phase tensor analysis was performed for data along Profiles A and B and the results (not shown) are consistent with those along Profile C.

Figure DR2. Pseudosections of observed data and model response for the apparent resistivity and phase along profiles A (a), B (b), and C (c). Black dots show data points.

Figure DR3. Two-dimensional (2D) potential field model along profile 1, developed using a 2D forward modeling package (GMSYS $®$ ). Measured rock property data from Ponce et al. (2009). Rock units consist of horizontal tabular prisms or blocks aligned with their longest axes perpendicular to the profile. Their surface extents are consistent in size, shape, and orientation with exposed rock units. The potential field model developed in Egger et al. (2010) was used as a starting model.

Table DR1. Summary of rock properties for units used in model shown in Figure DR3.

\section{References}

Caldwell, T.G., Bibby, H.M., and Brown, C., 2004, The magnetotelluric phase tensor: Geophysical Journal International, v. 158, p. 457-469.

Egger, A. E., Glen, J. M. G., and Ponce, D. A., 2010, The northwestern margin of the Basin and Range province: Part 2: Structural setting of a developing basin from seismic and potential field data: Tectonophysics, v. 488, no. 1-4, p. 150-161.

Ponce, D. A., Glen, J. M. G., Egger, A. E., Bouligand, C., Watt, J. T., and Morin, R. L., 2009, Geophysical studies in the vicinity of Warner Mountains and Surprise Valley, northeast California, northwest Nevada, and southern Oregon, in Survey, U. S. G., ed., p. 19. 